\title{
Articles
}

The Person and the Challenges

Volume 6 (2016) Number 2, p. 5-20

DOI: http://dx.doi.org/10.15633/pch.1866

Carl-Mario Sultana

University of Malta

\section{Educating through Communities of Practice}

\begin{abstract}
The aim of this paper is to attempt at building a bridge between education and situated learning. The etymology of the word education outlines the two major ways of envisioning education. The meaning which we give to the term 'education' surely influences the ways in which the process of education unfolds and is actually conducted. The Constructivist Approach which is being used in education today is characterised by its studentcenteredness rather than teacher-centeredness. The adoption of Communities of Practice from the industrial sphere to the realm of Catholic schools is a way in which education as bringing forth from the student (e-ducere) and the constructivist approach developed earlier can be put into practice in Catholic Schools. Communities of practice create the right condition for situated learning in Catholic schools today. It is here that legitimate peripheral participation can be put into practice, thus fulfilling the Church's mission of evangelisation in our contemporary culture by drawing students from the periphery of the educational endeavour, making them active participants at the core.
\end{abstract}

\section{Keywords}

Catholic Schools, Communities of Practice, Constructivist Approach, Education, Situated Learning. 
In our rapid day-to-day endeavours, trying to do as much as possible, but at times chasing the wind, "It's not a bad idea to occasionally spend a little time thinking about things you take for granted. Plain everyday things."' This holds even more true to words and terms which we encounter every day, and which are so basic and fundamental to either our living together or to our working together. Things taken for granted may mean that we neglect issues and nuances contained within them and which can make a world of difference in both our daily tasks and in the lives of other people. This is even more true for terms such as 'education' which not only influences the way in which we as educators envision our educational mission, but also and much more important is the fact that the way in which we think about education has a lasting effect on those who are at the receiving end of the process.

\section{What is 'education'?}

Education in a general way refers to the promotion and to the consolidation of the human person with the specific aim of helping the individual to live a free, conscious and responsible life in relation to others and to the created world. ${ }^{2}$ However, when we delve deeper down into the etymology of the word 'education' we encounter a first hurdle. Nobody is definitely sure about the real and proper roots of the word 'education'. One thing is for sure: the root of the word 'education' is coming for the Latin language. However, there are two nuances to the root of the word 'education'.

The first meaning is that it is a derivative of the Latin word educare, which refers to the process of providing nutrition to something or someone, to the process of breeding or cultivating. In this sense, education is more linked to organic processes such as growing, helping, taking hygienic care of something or someone. ${ }^{3}$ This way of understanding education constitutes the classical model of education where the contents were of utmost important, since what was absolutely necessary in education was the imparting of knowledge and skills which to the teacher had an intrinsic value. These contents were then presented

${ }^{1}$ E. Davis, BBC - Today: Evan Davis: Addressing the Chair, http://www.bbc.co.uk/blogs/ legacy/today/evandavis/2009/04/addressing_the_chair.html (02.03.2015).

${ }^{2}$ Cf. C. Nanni, Educazione, in: Dizionario di Scienze dell'Educazione, $2^{\text {nd }}$ edition, J. M. Prellezo, G. Malizia, C. Nanni (eds.), Roma 2008, LAS, p. 369.

${ }^{3}$ Cf. C. Nanni, Educazione, p. 369. 
to the student in an objective, clear and systematic way, in a specific order which was not influenced or based on the interests and the needs of the student. The teacher was considered as an expert and as a role model, while the student was an entirely passive recipient of the monologue. ${ }^{4}$

The second meaning of the term education may be coming from the Latin word educere (e-ducere), which literally means to draw out or to help someone or something to develop. In this sense, education refers more to a type of help which is offered to promote the interlocutor from an intellectual, emotional and relational point of view. It is aimed at helping the human being to use the gift of human reasoning and critical thinking. ${ }^{5}$ This meaning of the term education is linked to the interactional model of education. In this model, the teacher is responsible for creating a learning community, based on dialogue and interdependence in the class. In this model, the teacher is not seen as a person on a pedestal, but as a human being who has a more mature experience, through which the students can be stimulated and oriented to move forward and to get to know more about their capabilities. This outlook helps students to become more aware of their human dignity as persons, to make personal choices and to live their life accordingly. In this sense, education constitutes a process of rendering the human being more humane through a process of liberation and consciousness. ${ }^{6}$

This second meaning of the term 'education' is more in line with the contemporary holistic approach adopted in education today. In line with this vision, the human person is not simply considered as an empty bottle which teachers and educators are called to fill up with knowledge or information - something which is synonymous with the meaning of educare. On the other hand, considering education as educere, we will be taking into account the potentialities of the human being who can come to know things with the help of significant others.

This notion of education as bringing forth or helping the student to discover and bring to the light the hidden qualities and potentialities is in line with what the Soviet psychologist Lev Vygotsky (1896-1934) had referred to as the zone of proximal development when speaking about the education of children and adolescents. The zone of proximal development is made up of a lower limit and an

${ }^{4}$ Cf. M. Pellerey, Educare. Manuale di Pedagogia come Scienza Pratico-Progettuale, Roma 1999, LAS, p. 136-137; M. Pellerey and D. Grządziel, Educare. Per una Pedagogia Intesa Come Scienza Partico-Progettuale, $2^{\text {nd }}$ ed., Roma 2011, LAS, p. 158-159.

${ }^{5}$ Cf. C. Nanni, Educazione, p. 369.

${ }^{6}$ Cf. M. Pellerey, Educare, p. 139-140; M. Pellerey and D. Grządziel, Educare, p. 161-162. 
upper limit. The lower limit refers to those tasks and to that knowledge which the person can come to know by one's own proper self. The upper limit constitutes that which can be achieved with the help of a mentor. ${ }^{7}$ In our case, the mentor would be the teacher who will help the student to discover hidden potentialities and capabilities. The idea behind the concept of the zone of proximal development is linked to the notion of scaffolding. Scaffolding refers to the level of support offered to a person during the learning process. It is linked to the depth and difficulty used by the teacher with particular students, differentiating between gifted students and other students who require more time and help to learn something. ${ }^{8}$

\section{The Constructivist Classroom}

The Constructivist Approach applied to education is in line with this way of considering education as the process of leading students to discover their real self by helping them to discover their potentialities. In fact, it is also known as the student-centred approach. It needs to be considered in juxtaposition to the teacher-centred approach, which is more in line with considering education as a the simple imparting of knowledge to the students. The latter approach leads to looking at the process of education as indoctrination. The first consideration when speaking about the constructivist or student-centred approach is that constructivism is not a pedagogy, but a theory which attempts at explaining how learning is possible, and which ultimately fosters critical thinking in the students and creates more motivated and independent learners.

The differences between the teacher-centred approach and the student centred approach are neither minor, nor insignificant. In the teacher-centred approach, the primary importance is given to achieving the goals which the teacher has set, while the interest of the students is not given any importance.

7 Cf. L. S. Vygotsky, Mind in Society. The Development of Higher Psychological Processes, ed. M. Cole and others, Cambridge, Massachusetts - London 1978, Harvard University Press, p. 84-91; J. W. Santrock, Children, $12^{\text {th }}$ ed., New York, NY 2013, McGraw-Hill, p. 26-27, 263-267; J. W. Santrock, Adolescence, $13^{\text {th }}$ ed., New York - London 2010, McGraw-Hill, p. 30, 101-102; L. D. Steinberg, Adolescence, $9^{\text {th }}$ ed., New York 2010, McGraw-Hill, p. 77; J. J. Arnett and M. Hughes, Adolescence and Emerging Adulthood: A Cultural Approach, Harlow, England New York 2012, Pearson 2012, p. 121-122.

${ }^{8}$ Cf. J. W. Santrock, Children, p. 222-224, 264-266; L. D. Steinberg, Adolescence, p. 77; J. J. Arnett and M. Hughes, Adolescence and Emerging Adulthood, p. 121-122. 
The teacher simply hands out facts to the students, and the students do not need to worry that they are missing out on some important fact. This means that all the student has to do is to listen and to memorise. ${ }^{9}$ The student-centred approach or constructivist approach focusses mainly on the needs and interests of the students. In this sense, students are more in control of what they learn, thus becoming protagonists in their own education. This also gives way to more hands on activity which promotes higher order thinking and active roles. In the constructivist classroom, students have more freedom to choose those activities which interest them and which suits them most in their learning style, thus allowing for complementary learning styles to co-exist in the learning process. Moreover, the student-centred approach produces greater long-term positive results due to the fact that teachers become facilitators whose ultimate role is to provide structure and order in the class while allowing students to explore their own potentials. ${ }^{10}$ This produces an environment which is open, dynamic, respectful and trusting while respecting different learning styles.

The point of departure for considering whether the constructive approach is the best approach for education is by asking oneself about how one learns best. Is it by listening to somebody speaking about a particular theme, or is it by embarking on a process of discovering things for oneself with the mentorship of a teacher? It is surely the latter. This puts the constructive approach at a definite advantage to the teacher-centred approach. Through the constructivist approach, learning is an active process through which the student creates meaning from different experiences. Students learn best when they attempt and giving sense to something on their own, with the teacher simply acting as a guide to help and to support them along the way. ${ }^{11}$

9 Cf. Teacher-Centered vs. Student-Centered Education, http://education.cu-portland. edu/blog/classroom-resources/which-is-best-teacher-centered-or-student-centered-education (06.03.2015).

${ }^{10}$ Cf. Jacqueline Grennon Brooks and Martin G. Brooks, In Search of Understanding: The Case for Constructivist Classrooms, Alexandria, Va. 1993, Association for Supervision and Curriculum Development, p. 46-84; Teacher-Centered vs. Student-Centered Education; Rebecca Sue, The Importance of Child-Centred Learning, https://suite.io/rebecca-sue/20bc2ag (06.03.2015); E. Murphy, Characteristics of Constructivist Learning and Teaching, http://www. ucs.mun.ca/ emurphy/stemnet/cle3.html (06.03.2015).

${ }^{11}$ Cf. Grennon Brooks and Brooks, In search of Understanding, P. 4-5; Teaching with the Constructivist Learning Theory, https://www.nde-ed.org/TeachingResources/ClassroomTips/ Constructivist\%20_Learning.htm (07.03.2015). 
The student-centred classroom and the teacher-centred classroom differ from each other in that when the constructivist approach is used, the students interact with their teacher while being immersed in experiences within which they engage in enquiry, imagination, action and personal reflection. This gives more space to group work and to learning as a group through interaction. All this demonstrates that the emphasis is more on the student rather than on the teacher who is teaching. This involvement of the students in their learning process encourages them to be responsible and autonomous, whilst at the same time rendering the classroom environment more democratic. ${ }^{12}$ In practice, this is achieved by presenting multiple perspectives and representations which include both contents and concepts, which are aimed at facilitating the achievement of the objectives. These objectives are not set by the teacher but arrived at through a process of negotiation between the students and the teacher. The activities used for learning are all aimed at encouraging meta-cognition, self-analysis, self-regulation and self-reflection. These call for higher-order thinking and problem solving skills. ${ }^{13}$

The role of the teacher in all this active process of instruction is to facilitate through modelling, coaching and scaffolding. In this sense, the teacher is not simply seen as an expert who knows it all. The teacher assumes the role of a researcher along with the students by being able to incorporate the syllabus creatively and in a flexible way to the needs of the students. The learning situations, the classroom environment, skills, content and tasks used in a constructivist class need to be relevant, realistic, authentic and represent the natural complexities of the real world. ${ }^{14}$ At times this merely signifies that the teacher provides experiences for the students to study, reflect upon, manipulate, pose questions to, and investigate. Thus, the student-centred teacher elicits knowledge rather than just simply gives it to students. A pre-requisite for this type of classroom is dialogue as opposed to the monologue classroom of a teacher-centred approach. ${ }^{15}$

The student-centred approach does not do away with the student's previous knowledge, but attempts at using it as leverage to thrust the student into constructing new knowledge. On the other hand, errors committed by the student during the journey in search of knowledge constitute an opportunity

\footnotetext{
12 Cf. Grennon Brooks and Brooks, In search of Understanding, p. 15-22.

${ }^{13}$ Cf. E. Murphy, Characteristics of Constructivist Learning and Teaching.

${ }^{14}$ Cf. E. Murphy, Characteristics of Constructivist Learning and Teaching.

${ }^{15}$ Cf. Grennon Brooks and Brooks, In search of Understanding, p. 15-22.
} 
for insight into further inquiry and exploration. This provides students with a form of apprenticeship in which they experience increasing complexity in the tasks, skills and knowledge which they attempt at grasping in an interdisciplinary manner. ${ }^{16}$ It is here that the concept of 'scaffolding' comes to the fore-front. The scaffolding technique has been adopted in education from the civil engineering domain. In civil engineering, scaffolding is used to surround any structure which is being constructed and which is rising high towards the sky. Scaffolding makes it easier for builders to climb around the structure and to continue constructing at the top until the desired height is reached. In education, scaffolding refers to the variety of teaching resources and techniques which teachers use to progressively guide students towards a better grasp of their subject. When using scaffolding techniques, teachers are promoting greater independence during the learning process by offering successive levels of support which help students to acquire more knowledge and skills that they would not be able to achieve by themselves. Like scaffoldings used in civil engineering and which are then removed once the structure can stand alone, even in education, scaffolding provides support to students while they need it. Once they can work things out on their own, the scaffolding can be safely removed, thus handing on the responsibility to the student. ${ }^{17}$ This helps students to attempt at going just beyond their limits. This recalls Lev Vygotsky's zone of proximal development. ${ }^{18}$

\section{Catholic Education}

The discussion on education which has emerged thus far demonstrates the benefits of considering education as bringing forth, thus adopting a studentcentred or constructivist approach. At this point, a natural question arises: How can all this be implemented in Catholic education? Is it possible to practice this in Catholic schools? We must start by acknowledging that "Evangelizing is in fact the grace and vocation proper to the Church, her deepest identity. She exists in order to evangelize, that is to say, in order to preach and teach, to be the channel

16 Cf. E. Murphy, Characteristics of Constructivist Learning and Teaching.

17 Cf. Scaffolding Definition - The Glossary of Education Reform, http://edglossary.org/ scaffolding (01.04.2015).

${ }^{18}$ Cf. Murphy, Characteristics of Constructivist Learning and Teaching. 
of the gift of grace..."19 This evangelizing mission of the Church constitutes the fulfilment of Christ's mission to go and make disciples through teaching. ${ }^{20}$

Evangelisation is a complex process and if we try to capture its length and breath, we would be impoverishing it. In fact, evangelization entails a number of varied elements, amongst which we find witness, proclamation, initiation into the Christian community, and missionary initiatives. ${ }^{21}$ There are several ways in which these elements of evangelisation can be put into practice through the endeavours of a number of institutions. One of these institutions is the Catholic school. The primary aim of the Catholic school is to impart a Catholic education through all of its activities and not just through Religious Education. Catholic schools can be sources of evangelization through the three specific functions for which they exist, that is, to:

- develop in the school community an atmosphere animated by a spirit of liberty and charity;

- enable young people, while developing their own personality, to grow at the same time in that new life which has been given them in baptism;

- orientate the whole of human culture to the message of salvation. ${ }^{22}$

The Church can never relinquish or neglect its evangelising mission through Catholic schools. ${ }^{23}$

Although Catholic schools can be found in a variety of local and national situations and circumstances, still, when one delves deep into their ethos, one

19 Paul VI, Apostolic Exhortation Evangelii Nuntiandi (8 ${ }^{\text {th }}$ December 1975), http://w2. vatican.va/content/paul-vi/en/apost_exhortations/documents/hf_p-vi_exh_19751208_ evangelii-nuntiandi.html (06.03.2015), 14. This is also re-iterated in the General Directory for Catechesis, where we have that the church exists to evangelise, that is, proclaiming the Good News to every sector of society. Cf. Congregation for the Clergy, General Directory for Catechesis (15 ${ }^{\text {th }}$ August 1997) http://www.vatican.va/roman_curia/congregations/cclergy/documents/ rc_con_ccatheduc_doc_17041998_directory-for-catechesis_en.html) (06.03.2015), 46.

20 Cf. Mk 16, 15.

${ }^{21}$ Cf. Paul VI, Evangelii Nuntiandi, 24.

${ }^{22}$ Congregation for the Clergy, General Directory for Catechesis, 259.

${ }^{23}$ Cf. Congregation for Catholic Education, The Religious Dimension of Education in a Catholic School. Guidelines for Reflection and Renewal (7 $7^{\text {th }}$ April 1988), http://www.vatican. va/roman_curia/congregations/ccatheduc/documents/rc_con_ccatheduc_doc_19880407_ catholic-school_en.html (07.03.2015), 33; Congregation for Catholic Education, The Catholics School on the Threshold of the Third Millennium (28 ${ }^{\text {th }}$ December 1997), http://www.vatican. va/roman_curia/congregations/ccatheduc/documents/rc_con_ccatheduc_doc_27041998_ school2000_en.html) (07.03.2015), 3. 
finds that they are founded on the same basic principles: the values found in the Gospels. Notwithstanding the fact that all Catholic schools are based on the values found in the Gospels, they also share one common feature: they abide with the basic requisites for school curricula while at the same time, sustaining and promoting a Catholic ethos. It is exactly this that makes Catholic schools prototypes of education understood as educere, that is, as bringing forth and as helping the students to realise who they actually are, and what they are called to be.

The main aim of Catholic schools, besides that of promoting the intellectual development of the students, is to help them to get to know who they actually are: human beings created in the image and likeness of God and called to be his sons and daughters. This is what undergirds Catholic education in Catholic schools. ${ }^{24}$ Still, one needs to be careful not to render Catholic schools as school for indoctrination in the faith.

The temptation for Catholic schools to become fortresses where students become indoctrinated in the Catholic faith is not a remote consideration. School management teams in schools need to be constantly aware of this, and beware not to fall in the pitfall of rendering their schools unbalanced by negating a holistic education to all students. Catholic schools are called to give a balanced education to all students through a Catholic ethos, while not neglecting the other dimensions of human development: physical, social, moral, emotional and intellectual. ${ }^{25}$

The fact that Catholic schools are called to impart a holistic education to their students through their Catholic ethos does not preclude them from using studentcentred approaches; it is indeed an asset. Catholic education can be also effective on the curricular level by adopting a student-centred approach to education based on the constructivist approach. This means that the education given in Catholic

${ }^{24}$ Cf. Congregation for Catholic Education, The Religious Dimension of Education in a Catholic School, 1, 6, 34, 98-101; Congregation for Catholic Education, The Catholic School on the Threshold of the Third Millennium, 4-5, 8-10; Congregation for Catholic Education, Educating Together in Catholic Schools. A Shared Mission between Consecrated Persons and the Lay Faithful ( $8^{\text {th }}$ September 2007), http://www.vatican.va/roman_curia/congregations/ccatheduc/ documents/rc_con_ccatheduc_doc_20070908_educare-insieme_en.html (07.03.2015), 13.

25 Cf. Congregation for Catholic Education, The Religious Dimension of Education in a Catholic School, 34; Congregation for Catholic Education, Circular letter to the Presidents of Bishops' Conferences on Religious Education in Schools ( ${ }^{\text {th }}$ May 2009), http://www.vatican.va/ roman_curia/congregations/ccatheduc/documents/rc_con_ccatheduc_doc_20090505_circinsegn-relig_en.html (07.03.2015), 1, 19. 
schools, based on the concept of education as 'educere' will value the uniqueness of each student. Each and every student has good qualities and interests which render the process of education more effective for the student concerned.

Education in Catholic schools is not called to be a monologue but a dialogue between teachers and students, where what the student has to say is important and valid in the process of education. This implies that catholic education does not produce clones of students who are perfectly identical to each other, but it aims at targeting the needs and the interests of each and every student, aiming at involving all students in the process of their education, thus motivating them to see and consider whatever they learn in the context of the Catholic ethos of the school, and of the Catholic faith in general. ${ }^{26}$

\section{Developing Catholic Schools into Communities of Practice}

When teachers and the administration of a Catholic school strive to give a holistic Catholic education in their schools using student-centred approaches to education, one possible end-result is the formation of communities of practice within the school. The notion of a community of practice emerges from business related contexts and contexts of entrepreneurship. The whole idea behind communities of practice arose when different professionals working on the same product, but considering it from different points of view, found it easier and quicker to meet and discuss issues together rather than working on their own and then sending the product back to the drawing board when things did not match or fit. ${ }^{27}$ As time went by, communities of practice started to be considered as "groups of people who share a concern, a set of problems, or a passion about a topic, and who deepen their knowledge and expertise in this area by interacting on an ongoing basis." ${ }^{28}$ Communities of practice can take

${ }^{26}$ Cf. Congregation for Catholic Education, The Religious Dimension of Education in a Catholic School, 63, 101; Congregation for Catholic Education, The Catholic School on the Threshold of the Third Millennium, 1, 19; Congregation for Catholic Education, Educating Together in Catholic Schools, 2.

27 Cf. E. Wenger, R. A. McDermott and W. Snyder, Cultivating Communities of Practice: A Guide to Managing Knowledge, Boston, Mass. 2002, Harvard Business School Press, 1-4.

${ }^{28}$ E. Wenger, R. A. McDermott and W. Snyder, Cultivating Communities of Practice, 4; Cf. also J. Lave and E. Wenger, Situated Learning: Legitimate Peripheral Participation, Cambridge England - New York 1991, Cambridge University Press, p. 99-100. 
several forms: big or small, long-lived or short-lived, collocated or distributed, homogenous or heterogeneous, limited to particular boundaries or going beyond definite boundaries, planned or spontaneous, and institutionalised or noninstitutionalised. ${ }^{29}$

People in communities of practice do not necessarily encounter each other every day but they meet on a regular basis. These meetings give them a lot of meaning in life together with the possibility of sharing information, insights and advice. Over time, in these meeting they will then develop a body of knowledge and of practices and approaches to the things that they do in life. In other words, they develop a sense of belonging and of identity. Although originally communities of practice came into existence because they provided a way in which knowledge could be shared, they also help the individuals concerned in putting that knowledge into practice, and of living it if it is on a moral level. Members of the community of practice become a living repository for the knowledge acquired. ${ }^{30}$

Communities of practice offer the right environment for legitimate peripheral participation by creating a context where situated learning can take place. Situated learning does not simply refer to learning in a particular context, in our case the Catholic school. It refers to a deeper notion of education which implies and considers the entire human being during the process of education, thus being automatically holistic and comprehensive. In situated learning, it is not the body of knowledge made up of facts which stands at the centre of the educational process, but the human being as an agent in a mutual relationship with the world and all its activity. ${ }^{31}$

This is even more applicable to Catholic schools where all education is given from a Catholic perspective according to the Catholic ethos from which these schools take their actual name and characteristic. Moreover, Catholic schools through the situated learning environment which they provide to students, cater for legitimate peripheral participation.

Legitimate peripheral participation refers to the inclusion of people who do not form part of a group through a process of a step-by-step induction into 24-27.

${ }^{29}$ Cf. E. Wenger, R. A. McDermott and W. Snyder, Cultivating Communities of Practice,

${ }^{30}$ Cf. E. Wenger, R. A. McDermott and W. Snyder, Cultivating Communities of Practice, $4-5,9$.

${ }^{31}$ Cf. J. Lave and E. Wenger, Situated Learning, 33. 
the group, and into the beliefs and ways of practice of the community. This is indeed very close to the process of Christian Initiation. In the context of the Catholic school, students are slowly immersed into the Catholic ethos of the school through various curricular and extra-curricular activities. Moreover, all of these activities need to be considered not only as activities in themselves, but also in the student-centred approach adopted in their accomplishment.

"Legitimate peripheral participation" provides a way to speak about relations between newcomers and old-timers, and about activities, identities, artefacts, and communities of practice. A person's intentions to learn are engaged and the meaning of learning is configured through the process of becoming a full participant in a sociocultural practice. This social process includes, indeed it subsumes, the learning of knowledgeable skills. ${ }^{32}$

In any community of practice, there are three strata of participants: the core participants, the active participants and the peripheral participants. The core participants are the small group (usually $10 \%$ to $15 \%$ ) who hold key places in the community of practice, lead the group and may be also the leaders of the community of practice. At a more outer level, we find the active participants (usually 15\% to 20\%) who are interested in the community of practice and take active roles in the community. The outer most level is the level of the peripheral group, which constitutes the majority of the community of practice. The members of this group usually keep to the side-lines, watching and observing, but rarely take on an active role in the community of practice. ${ }^{33}$

This is also the case in Catholic schools, where we may have students coming from various strata of Catholicism. In a Catholic school, one can find a mixture of students coming from a range of families, varying from practicing families at one end to non-practicing families at the other extreme. This means that in a Catholic school, we may have students who are more-engaged or less-engaged in the Catholic ethos of the school. Moreover, since students are coming from different levels of families of practicing or non-practicing Catholics, we have the gradual mixture of students who feel at the centre and students who consider themselves on the periphery. One hopes that this natural mixing leads to the gradual insertion of those who are on the periphery into the centre. Participation is a foundational characteristic and a constitutive element which needs to be

32 J. Lave and E. Wenger, Situated Learning, 29.

${ }^{33}$ Cf. E. Wenger, R. A. McDermott and W. Snyder, Cultivating Communities of Practice, 55-58; J. Lave and E. Wenger, Situated Learning, 100-101. 
augmented through the Catholic ethos of the school, thus gradually inserting the student deeper into the community of practice, which in this case is the Catholic school. Thus, the Catholic school becomes an opening and a way of helping students who are at the periphery to gain access to active and practicing Catholics and eventually become active and practicing Catholics themselves. ${ }^{34}$

In considering communities of practice with their characteristic for enabling legitimate peripheral participation as a means to impart a Catholic education in Catholic schools, we need to be careful not to consider legitimate peripheral participation as a pedagogy in itself. It is only a way of understanding the dynamics of education which helps the student to move from being a simple spectator to becoming an active participant: We should emphasize, therefore, that legitimate peripheral participation is not itself an educational form, much less a pedagogical strategy or a teaching technique. It is an analytical viewpoint on learning, a way of understanding learning.....learning through legitimate peripheral participation takes place no matter which educational form provides a context for learning, or whether there is any intentional educational form at all. ${ }^{35}$

The notion of students who may be standing at the periphery, or at the core, or somewhere in between, is in line with the student-centred or constructivist approach, and with the Catholic ethos of Catholic schools. One must never forget that the main aim of the Catholic school is to impart a Catholic education, which leads students to acknowledge their status as human beings created in the image and likeness of God, and thus called to divine filiation. Communities of practice from their very nature promote the student-centred approach, while at the same time considering education as helping the student to develop latent potentialities. The student-centred approach is possible through communities of practice where legitimate peripheral participation is practiced only when education is seen by teachers as the process of helping students to develop their potentialities, and not as the internalisation and possession of knowledge by the student. In communities of practice, learning takes place in view of the holistic development of the students and of their relation to the world. In this sense, education is seen as the strengthening of a number of relations with others and with oneself, thus also implying becoming a full participant or member of a social or a faith-based community.

\footnotetext{
${ }^{34}$ Cf. J. Lave and E. Wenger, Situated Learning, 37.

35 J. Lave and E. Wenger, Situated Learning, 40.
} 
Education in a community of practice is therefore characterised by a constantly evolving form of membership, rather than a condition for membership. ${ }^{36}$ Legitimate peripheral participation in Catholic schools therefore "crucially involves participation as a way of learning - of both absorbing and being absorbed in - the 'culture of practice.' An extended period of legitimate peripherality provides learners with opportunities to make the culture of practice theirs." ${ }^{37}$ This is in contraposition to education as mere handing on of knowledge using a teacher-centred approach which does not even attempt at linking that knowledge with the student's experience and the world in which the student lives. ${ }^{38}$

The role of the teacher in enabling legitimate peripheral participation in Catholic schools is not marginal. Students are struck not so much with the novelty of what they are discovering, as with the witness, or modelling which teachers provide in their contact with students. Enabling students on the periphery to become active or core students to the community of practice requires teachers and educators who are mature in their outlook and practice as Catholics. The practice, guidance and sustenance of mature educators and teachers in Catholic schools provides the best type of apprenticeship required for students to become active participant in the community of practice which the Catholic ethos of their school promotes through all its activities. ${ }^{39}$

\section{Conclusion}

Education as bringing forth knowledge which the student already possess and as making the student aware of innate and invisible potentialities opens up a myriad of possibilities to the teacher or educator. One may start at the approach, which needs to be adopted, and which is in line with this vision of education. A teacher-centred approach is inadequate, since it does not exploit the potentialities of the student. On the other hand, a student-centred or constructivist approach provides the way forward for a holistic education

\footnotetext{
${ }^{36}$ Cf. J. Lave and E. Wenger, Situated Learning, 49-53.

37 J. Lave and E. Wenger, Situated Learning, 95.

${ }^{38}$ Cf. J. Lave and E. Wenger, Situated Learning, 47.

${ }^{39}$ Cf. J. Lave and E. Wenger, Situated Learning, 110.
} 
that makes students aware of their intrinsic and latent qualities. Catholic schools are modern fora for evangelising future generations. The massive task of evangelisation can be accomplished by rendering our schools special places where communities of practice based on the Catholic ethos of schools can be established and experienced. Communities of practice, on their behalf, constitute the right context for legitimate peripheral participation through situated learning. Through legitimate peripheral participation, students at the periphery of the Catholic faith will have the opportunity to mix with students who are at the core of the Catholic faith and who are therefore active and practicing Catholics. When the Catholic school provides the right context for such communities of practice, it is fulfilling the Church's mission of evangelisation of which it forms an active part.

\section{Bibliography}

Arnett J.J. and Hughes M., Adolescence and Emerging Adulthood: A Cultural Approach, Harlow, England - New York 2012, Pearson.

Brooks J.G. and Brooks M.G., In Search of Understanding: The Case for Constructivist Classrooms, Alexandria, Va. 1993, Association for Supervision and Curriculum Development.

Congregation for Catholic Education, Circular letter to the Presidents of Bishops' Conferences on Religious Education in Schools (5 ${ }^{\text {th }}$ May 2009). (online: http://www. vatican.va/roman_curia/congregations/ccatheduc/documents/rc_con_ccatheduc_ doc_20090505_circ-insegn-relig_en.html) (07.03.2015).

Congregation for Catholic Education, Educating Together in Catholic Schools. A Shared Mission between Consecrated Persons and the Lay Faithful ( $8^{\text {th }}$ September 2007). (online: http://www.vatican.va/roman_curia/congregations/ccatheduc/documents/ rc_con_ccatheduc_doc_20070908_educare-insieme_en.html) (07.03.2015).

Congregation for Catholic Education, The Catholics School on the Threshold of the Third Millennium (28 ${ }^{\text {th }}$ December 1997). (online: http://www.vatican.va/roman_curia/ congregations/ccatheduc/documents/rc_con_ccatheduc_doc_27041998_school2000_ en.html) (07.03.2015).

Congregation for Catholic Education, The Religious Dimension of Education in a Catholic School. Guidelines for Reflection and Renewal ( $7^{\text {th }}$ April 1988). (online: http://www. vatican.va/roman_curia/congregations/ccatheduc/documents/rc_con_ccatheduc_ doc_19880407_catholic-school_en.html) (07.03.2015).

Congregation for the Clergy, General Directory for Catechesis (15 ${ }^{\text {th }}$ August 1997). (online : http://www.vatican.va/roman_curia/congregations/cclergy/documents/ rc_con_ccatheduc_doc_17041998_directory-for-catechesis_en.html) (06.03.2015). 
Davis E., BBC - Today: Evan Davis: Addressing the Chair. (online: http://www.bbc.co.uk/ blogs/legacy/today/evandavis/2009/04/addressing_the_chair.html) (02.03.2015).

Lave J. and Wenger E., Situated Learning: Legitimate Peripheral Participation. Learning in Doing, Cambridge England - New York 1991, Cambridge University Press.

Murphy E., Characteristics of Constructivist Learning and Teaching. (online: http://www. ucs.mun.ca/ emurphy/stemnet/cle3.html) (06.03.2015).

Paul VI, Apostolic Exhortation Evangelii Nuntiandi ( $8^{\text {th }}$ December 1975). (online: http://w2.vatican.va/content/paul-vi/en/apost_exhortations/documents/hf_ p-vi_exh_19751208_evangelii-nuntiandi.html) (06.03.2015).

Pellerey M. and Grządziel D., Educare. Per una Pedagogia Intesa Come Scienza Partico-Progettuale, Enciclopedia Delle Scienze Dell'Educazione, $2^{\text {nd }}$ ed., Roma 2011, LAS.

Pellerey M., Educare. Manuale di Pedagogia come Scienza Pratico-Progettuale, Roma 1999, LAS.

Prellezo J.M., Guglielmo Malizia and Carlo Nanni, eds. Dizionario di Scienze dell'Educazione, $2^{\text {nd }}$ edition, Roma 2008, LAS.

Santrock J.W., Adolescence. $13^{\text {th }}$ ed., New York - London 2009, McGraw-Hill.

Santrock J.W., John W., Children, $12^{\text {th }}$ ed., New York, NY 2013, McGraw-Hill.

Scaffolding Definition - The Glossary of Education Reform (online: http://edglossary.org/ scaffolding) (01.04.2015).

Steinberg L.D., Adolescence, $9^{\text {th }}$ ed., New York 2010, McGraw-Hill.

Sue R., The Importance of Child-Centred Learning (online: https://suite.io/rebeccasue/20bc2ag) (06.03.2015).

Teacher-Centered vs. Student-Centered Education. (online: http://education.cu-portland. edu/blog/classroom-resources/which-is-best-teacher-centered-or-student-centered-education) (06.03.2015).

Teaching with the Constructivist Learning Theory. (online: https://www.nde-ed.org/ TeachingResources/ClassroomTips/Constructivist\%20_Learning.htm) (07.03.2015).

Vygotsky L.S., Mind in Society. The Development of Higher Psychological Processes, edited by Cole, Michael, Vera John-Steiner, Sylvia Scribner and Ellen Souberman, Cambridge, Massachusetts - London 1978, Harvard University Press.

Wenger E., McDermott R.A., and Snyder W., Cultivating Communities of Practice: A Guide to Managing Knowledge, Boston, Mass. 2002, Harvard Business School Press. 